Sakharov

\section{No more fences about Sakharov}

ANDREI Sakharov is a saint, his friends say, but he is a saint in crumpled trousers, a well-used lumberjack shirt and a kind of cycling jacket made of wine-red velour which he wears open at the neck. It is easy to forget that he was the one who, with Ya B. Zeldovich, sketched out the principles on which Soviet hydrogen bombs were developed when he was a mere 32 , and that he made his first protest about the international arms race as far back as 1961.

Since Sakharov and his wife Elena Bonner returned from his seven-year exile in Gorkii in December 1986, they have lived in an apartment near the Kurskii Railway terminal occupied by Mrs Bonner's mother, who spent part of her daughter's exile in the United States, but who has now returned.

Sakharov and his wife are late owls. $\mathrm{He}$ works at the Lebedev Institute, all day, relaxes over dinner, and then starts work

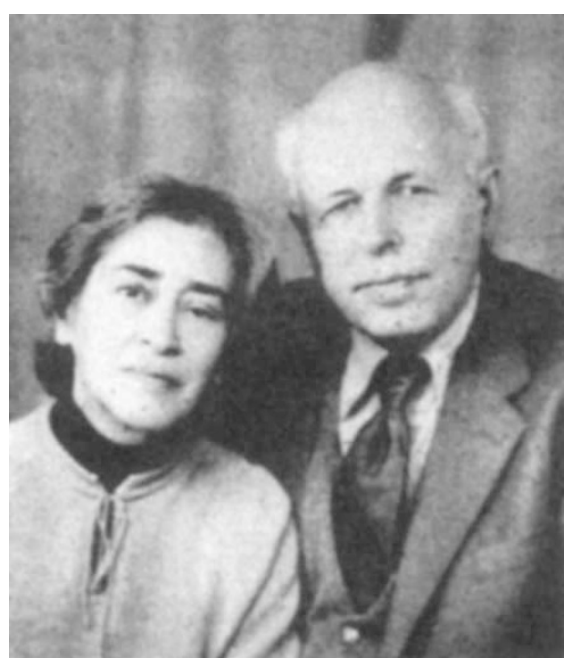

Sakharov and his wife, Yelena Bonner, soon after hearing that their seven-year internal exile was to end.

again at nine o'clock or so. IBM may have influenced his working pattern by equipping him with a late-model personal computer, complete with one of the few personally owned printers in the Soviet Union.

Sakharov appears entirely without guile, willing to tackle even the most direct questions directly. It is almost as if he feels he has an obligation to answer any question put to him. He likes to develop his opinion, which is natural enough in one kept to himself for seven years. His friends offer a running commentary on what he says and his wife makes splendid coffee in the tiny kitchen in which people also eat.

Sakharov is, to say the least of it, disappointed that his fellow academicians did so little to help him during his exile. It would not be an exaggeration to say that he is bitter about the whole business. It is particularly hurtful to him that four members of the academy should have denounced him vituperatively in a letter published in the newspapers. He can understand why Academician G.K. Skryabin, the academy secretary, signed the letter, but why should A.M. Prokhorov, otherwise a decent fellow, have added his name?

Another source of discontent is that there is no sign that the authorities plan to return the medals he was awarded (with Zeldovich) for his work on the development of nuclear weapons, of which he was stripped at the outset of his exile. Zeldovich, sporting an exactly similar set of medals on the first day of the sputnik celebrations earlier this month ("We were told to wear them"), explained their absence on the second day by saying "How can I wear them in the presence of Sakharov, who is equally entitled to them?"

Sakharov is also mildy resentful (but not particularly surprised) that the video film of him in apparently good health, which was widely distributed in the West in the months before his exile ended, had been made by the use of the "candid camera" techniques of hidden cameras.

On the state of Soviet science, Sakharov says it is no surprise that theoretical research is stronger than experimental work; the shortage of equipment is a sufficient explanation. But he agrees with the opinion of another guest that Soviet physicists often drop projects when it would be more profitable to follow through, as with the discovery of superfluidity in liquid helium-III in the past decade.

$\mathrm{He}$ is also worried by the wayward tendency among Soviet scientists to follow eccentric leads and also to tolerate eccentric leaders, of whom Lysenko ("far from being a simple fool") is the best known.

Sakharov recalls with a blend of wonder and amusement the troubles in the early 1950 s over the interpretation of quantum mechanics; Bohr and all his works at Copenhagen were then roundly condemned as idealists (then a term of abuse) by people such as Terletsky and Ivanenko. In the end, it took the intervention of Kapitza to quash the dissident movement. Now the Soviet scientific community as a whole is probably too jealous of its reputation elsewhere to tolerate waywardness on a scale that matters.

The need now, Sakharov believes, is for more durable contacts between the Soviet Union and the outside world - "uncontrolled migration", he calls it. But creative contact with the outside world cannot be maintained by "business trips" and, it goes without saying, "those who are invited" from elsewhere "should be those who are sent". "Nobody can tell who will bring the new ideas".

On the future of arms control, Sakharov is surprisingly cautious. He supports $\mathrm{Mr}$ Mikhail Gorbachev's initiatives, but emphasizes that the motives are domestic, mostly economic. "He has to release resources." He welcomes the prospect of an agreement on missiles of intermediate range, but is anxious that this should not provoke a loosening of US influence or a decline of US interest in Western Europe. (Mrs Bonner quickly dismisses as a "Western idea" the suggestion that the other side of that coin might be lessened Soviet zeal in controlling what happens in Eastern Europe.)

Sakharov is looking for other kinds of international agreements, not yet much discussed. On the grounds that the world will need nuclear power for the next century, but because of the consequences of the accident at Chernobyl, he would like to see an international agreement to put all reactors underground. He would also like to see a comprehensive test-ban, to

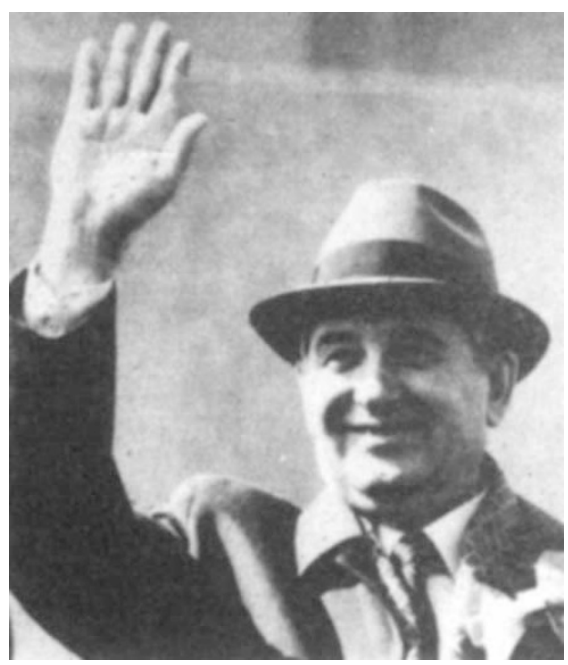

Sakharov's release? Mikhail Gorbachev's call with the good news came on a newly installed telephone.

which there is now no obstacle.

For the rest, in this small kitchen to which the whole world seems to be beating a path, there is some casual conversation about general relativity, speculation about what may lie beneath, or beyond, the much publicized row between a member of the Politburo and the editor of Moscow News (see p. 783), one copy of which is passed round the table.

Only when trying to persuade a taxi to go in the right direction did our fellow guest explain that he had not visited the Soviet Union (where he had been born) since Sakharov was locked up. "He really is a saint", he said.

Sakharov may be glad to be away from Gorkii, but is not now cheerfully looking forward to an unclouded future. There may be promise ahead, but there are also great dangers, especially for saints. 